\title{
Punakawan Sebagai Inspirasi Penciptaan Film Pendek Animasi Bertema Pendidikan Karakter
}

\author{
Arif Sulistiyono \\ Program Studi Animasi, Fakultas Seni Media Rekam, \\ Institut Seni Indonesia Yogyakarta \\ e-mail: arifgokong@gmail.com
}

\begin{abstract}
Abstrak
Animasi edukasi adalah sebuah produk animasi yang diproduksi khusus untuk tujuan pembelajaran. Popularitasnya dalam membantu peserta didik memahami dan mengingat informasi yang disajikan meningkat sejak munculnya teknologi komputer grafis. Kurangnya peningkatan produksi karya film pendek animasi di Indonesia mengakibatkan sedikitnya dijumpai karya-karya animasi edukasi buatan anak negeri. Rangsangan penciptaan karya animasi berbasis pada budaya lokal sepatutnya menjadi perhatian bagi para kreator dalam menghasilkan film animasi Indonesia. Hal inilah yang mendorong ide penelitian dan penciptaan karya guna menambahkan karya alternatif tontonan bagi anak-anak supaya lebih bervariatif. Karya yang dihasilkan nantinya diharapkan mampu menjadi salah satu tolok ukur bagi pencipta-pencipta film pendek animasi di Indonesia.

Film pendek animasi yang bertemakan pendidikan karakter dan memiliki ciri penokohan dan desain berbasis kearifan lokal masih sangat sedikit. Produksi karya masih didominasi oleh unsur-unsur humoris yang mempertontonkan aspek kekerasan sebagai layaknya hal yang umum dilakukan. Hal ini sangat berbahaya dikarenakan perkembangan kepribadian atau karakter sang anak secara tidak langsung akan didominasi oleh tontonan hiburan yang kurang mendidik. Oleh karena itu memunculkan kembali tokoh-tokoh Punakawan selaku "guru" pendidikan karakter dalam wujud karya film pendek animasi sangatlah perlu direalisasikan demi pertumbuhan pendidikan karakter generasi penerus bangsa Indonesia dikemudian hari.
\end{abstract}

Kata kunci: Animasi edukasi, punakawan, pendidikan karakter

\section{Abstrak}

Educational animation is an animated product produced specifically for the purpose of learning. Its popularity in helping students understand and remember information presented increased since the advent of computer graphics technology. The lack of an increase in the production of animated short films in Indonesia resulted in at least encountered the works of domestically-made animation education. Stimulation of creation of animated works based on the local culture should be a concern for creators to produce Indonesian animated film. This has encouraged the idea of research and the creation of the works to add alternative work spectacle for children to be more varied. The work produced will be expected to become one of the benchmarks for the creators of short animated films in Indonesia.

The short animated film themed character education and have the characterization and design characteristics based on local wisdom is still a little bit. Production work is still dominated by elements that showed the humorous aspects of violence as like a common thing to do. It is extremely dangerous due to the development of the child's personality or 


\section{Arif Sulistiyono}

Punakawan Sebagai Inspirasi Penciptaan Film Pendek Animasi Bertema Pendidikan

Karakter

character will indirectly entertained spectacle dominated by the less educated. Therefore bring back figures Punakawan as "teacher" character education in the form of short animated films for the sake of growth is necessary to be realized next generation character education in Indonesia.

Keywords: educational animation, punakawan, moral education

\section{Pendahuluan}

Memasuki abad ke-21 banyak pendidik ingin menekankan kembali hadirnya pendidikan budi pekerti dalam konteks pendidikan karakter untuk mempromosikan nilai-nilai positif bagi anak-anak muda seiring dengan merebaknya perilaku kekerasan dalam masyarakat. Brooks dan Goble (1997: 103) bahkan mengindikasikan bahwa kejahatan dan bentuk-bentuk lain perilaku tidak bertanggungjawab telah meningkat dengan kecepatan yang sangat mengkhawatirkan dan telah merembes menembus berbagai macam aspek kehidupan sehari-hari dan telah menjadi proses reproduksi sosial. Mereka juga menambahkan bahwa masyarakat saat ini sedang kehilangan rasa hormat pada orang lain serta pupusnya etika profesi. Secara ekstrim bahkan dikatakan bahwa kemerosotan moral ini telah menjadi ciri khas kultur abad ke-20 (West, 1999: 5). Hal ini disadari pemerintah sehingga melalui Kementerian Pendidikan Nasional mencanangkan program "Pendidikan Budaya dan Karakter Bangsa" sebagai gerakan nasional pada tanggal 14 Januari 2010.

Secara historis persoalan karakter bangsa juga pernah didengungkan presiden pertama Indonesia, Ir. Soekarno. Ia berpendapat bahwa pembangunan karakter sangat diperlukan demi tegak dan kokohnya jati diri bangsa agar mampu bersaing di dunia global, seperti yang ia gelorakan dalam tema besar "Nation and Character Building”. Beliau berpesan kepada kita bangsa Indonesia, bahwa tugas berat untuk mengisi kemerdekaan adalah membangun karakter bangsa. Apabila pembangunan karakter bangsa ini tidak berhasil, maka bangsa Indonesia akan menjadi bangsa kuli (H. Soemarno Soedarsono, 2009: sampul).

Namun ironisnya, anak-anak dan remaja yang menjadi salah satu target sasaran tidak sepenuhnya mendapat asupan pendidikan karakter baik secara formal di sekolah maupun melalui lingkungan masyarakat. Televisi yang seharusnya mempunyai tanggungjawab moral dalam menyebarluaskan pesan kebaikan tidak 